\title{
Blood Drive Day-related Factors Affecting University Student Blood Donation in Grenada, West Indies: A Case-control Study
}

\author{
SN Hewitt ${ }^{1}$, LLMcV Messam²
}

\begin{abstract}
Objective: To determine what factors acting in close temporal proximity to the day of a university campus blood drive are associated with university student blood donation.

Methods: An incidence density case-control study was conducted at St George's University, Grenada, West Indies. Cases (69) were students interviewed while donating blood at blood drives (February to April 2010). Controls (437) were non-donating students interviewed on the same days as cases. Exposures of interest were: sources of knowledge of the blood drive, the presence or lack of academic deadlines within a week of the blood drive, and the number of hours of classes on the day of the blood drive. Data were analysed using logistic regression with adjusted odds ratios approximating risk ratios (RRs).

Results: Associations with blood donation were higher for electronic and/or personal $\left(R R_{\text {Email }}=\right.$ 5.1; $95 \%$ confidence interval (CI): 2.7, 9.6; $R R_{\text {Facebook }}=4.3 ; 95 \%$ CI: 2.1, 9.0; $R R_{\text {PersonalReminder }}=$ 2.9; 95\% CI: 1.6, 5.4) than for impersonal $\left(R R_{\text {Classannouncement }}=2.4 ; 95 \%\right.$ CI: 1.3, 4.8) sources of knowledge of the blood drive. Additionally, students with classes only in the morning $\left(R R_{\text {AMonly }}\right.$ $=1.5 ; 95 \%$ CI: $0.7,2.9)$ or only in the afternoon $\left(R R_{P M o n l y}=1.9 ; 95 \% C I: 1.2,3.2\right)$ and those with no academic deadlines within a week of the blood drive were more likely to donate blood. Conclusion: University student blood donation showed a stronger association with personal and/or electronic advertising than with impersonal and/or non-electronic advertising. University blood drives should target students with similar timetables at times of reduced academic stress using personal and electronic modes of advertising.
\end{abstract}

Keywords: Blood donation, Grenada, university students

\section{Factores relacionados con el Día del Donante de Sangre que afectan la donación de sangre de los estudiantes universitarios en Granada, Antillas: un estudio de casos y controles}

SN Hewitt ${ }^{1}$, LLMcV Messam²

\begin{abstract}
RESUMEN
Objetivo: Determinar qué factores próximos al día de la campaña de donación de sangre en una universidad se asocian con la donación de sangre de los estudiantes universitarios.
\end{abstract}

From: ${ }^{1}$ ETSU Family Physicians of Kingsport, Department of Family Medicine, Quillen College of Medicine, East Tennessee State University, Kingsport, TN 37660, United States of America and ${ }^{2}$ Section of Herd Health and Animal Husbandry, School of Veterinary Medicine, College of Health and Agricultural Sciences, University College Dublin, Dublin, Ireland.
Correspondence: Dr LLMcV Messam, Section of Herd Health and Animal Husbandry, School of Veterinary Medicine, College of Health and Agricultural Sciences, Veterinary Science Centre, University College Dublin, Belfield, Dublin 4, Ireland. Email: locksley.messam@ucd.ie 
Métodos: Se realizó un estudio de casos y controles con muestreo por densidad de incidencia en la donación de sangre en la Universidad de Saint George, Granada, Antillas. Los casos (69) eran estudiantes entrevistados durante la campaña de donación (febrero a abril de 2010). Los controles (437) eran estudiantes no donantes entrevistados en los mismos días que los casos. Las manifestaciones de interés fueron: las fuentes de la información sobre la campaña de donación, la presencia o ausencia de fechas topes de tareas académicas en el plazo de una semana antes y después de la campaña de donación, y el número de horas de clases en el día de la donación. Los datos se analizaron usando la regresión logística con razones de posibilidades (odds ratios) ajustados aproximados a las razones de riesgo (RRs).

Resultados: Las asociaciones con la donación de sangre eran más altas para las fuentes electrónicas y/o personales de información de la campaña $\left(R R_{\text {Correo electrónico }}=5.1 ; 95 \%\right.$ intervalo de confianza (IC): 2.7, 9.6; $R R_{\text {Facebook }}=4.3 ; 95 \%$ IC: 2.1, 9.0; $R R_{\text {recordaorio personal }}=2.9 ; 95 \%$ IC: 1.6 , 5.4) que para las fuentes impersonales $\left(R R_{\text {anuncios en clase }}=2.4 ; 95 \% I C: 1.3,4.8\right)$. Además, los estudiantes con clases sólo en la mañana $\left(R R_{\text {AMsólo }}=1.5 ; 95 \%\right.$ IC: $\left.0.7,2.9\right)$ o sólo por la tarde $\left(R R_{P M s o ́ l o}=1.9 ; 95 \%: 1.2,3.2\right)$ y aquellos sin fechas topes para tareas académicas en el plazo de una semana antes y después de la campaña de la donación de sangre fueron más propensos a donar sangre.

Conclusión: La donación de sangre de los estudiantes de la Universidad demostró una asociación más fuerte con la publicidad personal y/o electrónica que con la publicidad impersonal y/o no-electrónica. Las campañas de donación de sangre en la Universidad deben dirigirse a los estudiantes con horarios similares en los periodos de menos tensión académica usando modos personales y electrónicos de publicidad.

Palabras clave: Donación de sangre, Granada, estudiantes universitarios

\section{West Indian Med J 2018; 67 (3): 219}

\section{INTRODUCTION}

Research on tertiary student blood donors has largely described their knowledge, attitudes, beliefs and experiences of blood donation (1-15), with studies reporting between $10 \%$ and $83 \%$ of student participants having had at least one previous blood donation experience $(1-7,9-12,16)$. Common motivations for blood donation among students have been humanitarian or altruistic $(5,7,17,18)$, self-satisfaction (4), the need to help a friend or relative $(14,16)$, and national catastrophes $(14$, 16). Frequently cited reasons for non-donation are medical (including safety) concerns $(4,7,12,14-16,18)$, fear $(4,7,9,10,15,16,18-20)$, and a lack of time $(4,9$, $15,16)$. Notwithstanding this research, questions remain as to the specific reasons why students may or may not donate blood at any given blood drive and why there is a substantial difference between the percentage who view blood donation positively and those who actually donate $(4,9,15,21-23)$. It is likely that transient factors occurring in close temporal proximity to a blood drive play a major role in determining whether or not donation occurs. Such factors are likely to include the medium through which the blood drive is advertised to students, class schedules and the presence or lack of academic deadlines (including assignment deadlines and assessments). Possibly because this seems intuitive, the effects of these factors on actual blood donation have not been evaluated. While this is best done by comparing the incidence of blood donation among students with and without the factor in question, paradoxically, blood donation is often not the outcome investigated in studies of blood donation. Many studies are conducted outside of the context of blood drives (1-5, 7-14, 16-18, 20-23) and/or compare (often cross-sectionally) characteristics of students with and without histories of blood donation $(1-16,19)$.

To determine whether specific student-related factors occurring in close temporal proximity to the day of a university campus blood drive were associated with student blood donation, we conducted an incidence density casecontrol study at St George's University (SGU), Grenada, West Indies. This project was part of a wider collaborative effort, 'The Blood for Grenada Project' as described elsewhere $(24,25)$. 
In Grenada, the Grenada Blood Bank's (GBB) current intake is approximately 14 units per 1000 inhabitants per year, substantially short of the required 50 units per 1000 inhabitants as estimated by the World Health Organization and the International Federation of Red Cross and Red Crescent Societies (26). The country is heavily dependent on family donations for blood transfusions, and there is little promotion or education on blood donation. In 2005, SGU's chapter of the American Medical Student Association began organizing on-campus blood drives at SGU's health clinic in order to contribute to the GBB's stores. These blood drives were held once a month during the academic year with each one resulting in 10-25 student donations out of a population of approximately 3300 students. Apart from these student-supported blood drives, there were no structured or regular blood drives on the island.

\section{SUBJECTS AND METHODS}

\section{Study population}

The study population consisted of students in the three divisions of SGU: School of Arts and Sciences, School of Veterinary Medicine and School of Medicine. The study was approved by SGU's institutional review board (Protocol no. 10002). Data were collected via in-person interviews conducted by 30 trained student interviewers, 22 of whom had recently obtained their Master of Public Health degrees at SGU. Questionnaires were administered only during the hours (9am-3pm) of the once-a-month blood drive which was held on the second Wednesday of February, March and April 2010.

\section{Exposure information}

Data collected from study participants included demographic characteristics, information pertaining to how they learnt about or were reminded of the blood drive during the week preceding the blood drive, academic assignments with deadlines within a week of the blood drive, and the number of hours of classes they had on the day of the blood drive.

\section{Cases}

Cases were students who entered the SGU health clinic and successfully gave blood at any one of the three monthly blood drives held in February, March and April 2010. Cases were interviewed during blood donation to eliminate the possibility of misclassification and reduce the demand on students' time. All students who donated blood during the study period were enrolled as cases.

\section{Controls}

Controls were students who had not donated blood at any of the monthly blood drives in February, March or April 2010, prior to being interviewed for the study. Controls were selected only on the days of the blood drive and only from $9 \mathrm{am}$ to $3 \mathrm{pm}$. Interviews with controls were conducted at eight different high-traffic locations on campus: library, bus stops, cafeterias, study hall entrances, and other places adjacent to areas of high classroom concentration for each SGU school. These locations were selected based on previous input from students indicating the locations with the highest pedestrian traffic on campus.

\section{Statistical analysis}

Sixty-nine (all) cases and 437 controls were used for final data analyses in SPSS Statistics software, version 20. Exposures of interest were: the means by which students learnt about or were reminded of the blood drive, the presence or lack of academic deadlines within a week of the blood drive, and the number of hours of classes they had on the day of the blood drive. Specific pairs of factors related to how students learnt about the blood drive were also combined as joint exposures of interest. For each exposure of interest, initially, a subset of potential confounders was created using directed acyclic graphs (DAGs) (27). We then used logistic regression and the change-in-estimate procedure with forward selection to select confounders from each DAG-based subset to estimate odds ratios (ORs) for blood donation. A 10\% criterion was used for inclusion of a potential confounder in final regression models (28). From final models, for each exposure of interest, adjusted ORs and their $95 \%$ confidence intervals (CIs) were used to approximate risk ratios (RRs) and associated 95\% CIs, given that the incidence of blood donation on SGU campus was less than 1\% (29).

\section{RESULTS}

\section{Demographic characteristics}

Table 1 provides demographic information on cases and controls. Among cases and controls, median ages (24 years) and inter-quartile age ranges (22-26 years) were the same, with the age range for cases (17-40 years) narrower than that for controls (16-50 years). Age did not meet the $10 \%$ criterion for inclusion in any final model.

\section{Source of information about the blood drive}

When the effects of individual sources of information about the blood drive were examined, each was 
Table 1: Distribution of blood donors (cases) and non-donors (controls) by gender, nationality, residence and school, St George's University campus blood drive, Grenada, West Indies, February to April 2010

\begin{tabular}{|c|c|c|c|}
\hline Exposure & Categories & $\begin{array}{l}\text { Cases } \\
\text { n (\%) } \\
\end{array}$ & $\begin{array}{l}\text { Controls } \\
\text { n (\%) } \\
\end{array}$ \\
\hline \multirow[t]{3}{*}{ Gender } & Female & $44(64)$ & $260(59)$ \\
\hline & Male & $25(36)$ & $177(41)$ \\
\hline & Total & 69 & 437 \\
\hline \multirow[t]{4}{*}{ Nationality } & Caribbean $^{\mathrm{a}}$ & $11(16)$ & $188(43)$ \\
\hline & North American ${ }^{\mathrm{b}}$ & $50(72)$ & $204(47)$ \\
\hline & Other ${ }^{c}$ & $8(12)$ & $43(10)$ \\
\hline & Total & 69 & 435 \\
\hline \multirow[t]{4}{*}{ Residence } & On campus & $35(51)$ & $99(23)$ \\
\hline & $\begin{array}{l}\text { Off campus } \\
\text { (True Blue area) }^{\mathrm{d}}\end{array}$ & $11(16)$ & $76(17)$ \\
\hline & $\begin{array}{l}\text { Off campus } \\
\text { (non-True Blue } \\
\text { area) })^{\mathrm{e}}\end{array}$ & $23(33)$ & $259(60)$ \\
\hline & Total & 69 & 434 \\
\hline \multirow[t]{4}{*}{ School } & $\begin{array}{l}\text { Arts and } \\
\text { Sciences }\end{array}$ & $13(19)$ & $186(43)$ \\
\hline & Medicine & $53(77)$ & $229(52)$ \\
\hline & $\begin{array}{l}\text { Veterinary } \\
\text { Medicine }\end{array}$ & $3(4)$ & $21(5)$ \\
\hline & Total & 69 & 436 \\
\hline
\end{tabular}

${ }^{a}$ Caribbean islands and Guyana

${ }^{\mathrm{b}}$ United States of America, Canada

${ }^{\mathrm{c}}$ Non-Caribbean and non-North American

${ }^{d}$ Approximately within a one-mile radius from St George's University campus

e Approximately outside of a one-mile radius from St George's University campus

associated with at least a two-fold increase in the likelihood of blood donation (Table 2). Risk ratios for donating blood were also higher for students who learnt about the blood drive via electronic means (versus those who did not) than for students who learnt through nonelectronic means (versus those who did not) (Table 2).

When the effects of selected combinations of information sources were investigated, RRs for donating blood were highest for combinations which included an electronic communication, followed by combinations which included no electronic communication but included a personal communication, followed by combinations which included neither electronic nor personal communication (Table 3). Most RRs for the joint information sources were also greater than the RRs of either of the component sources taken individually (Table 3). Exceptions to this were observed for the combinations of sign and class announcement and class announcement and email. For example, students who had seen a sign on campus and
Table 2: Distribution of blood donors (cases) and non-donors (controls) by source of blood drive information along with adjusted risk ratios (RRs) and 95\% confidence intervals (CIs) for associations between source of information and blood donation, St George's University campus blood drive, Grenada, West Indies, February to April 2010

\begin{tabular}{|c|c|c|c|c|c|}
\hline $\begin{array}{l}\text { Source of blood drive } \\
\text { information }\end{array}$ & Categories & $\begin{array}{l}\text { Cases } \\
\text { n }(\%)^{\mathrm{a}}\end{array}$ & $\begin{array}{l}\text { Controls } \\
\text { n }(\%)^{\mathrm{a}}\end{array}$ & $\mathbf{R R}$ & $\begin{array}{l}95 \% \\
\text { CI }\end{array}$ \\
\hline \multirow[t]{3}{*}{ Email $^{\mathrm{b}}$} & Yes & $23(36)$ & $37(9)$ & 5.1 & $2.7,9.6$ \\
\hline & No & $41(64)$ & $384(91)$ & 1 & \\
\hline & Total & 64 & 421 & & \\
\hline \multirow[t]{3}{*}{ Facebook post ${ }^{\mathrm{b}}$} & Yes & $16(25)$ & $22(5)$ & 4.3 & $2.1,9.0$ \\
\hline & No & $48(75)$ & $399(95)$ & 1 & \\
\hline & Total & 64 & 421 & & \\
\hline \multirow[t]{3}{*}{ Saw donor ${ }^{c}$} & Yes & $9(14)$ & $21(5)$ & 3.5 & $1.6,5.4$ \\
\hline & No & $55(86)$ & $399(95)$ & 1 & \\
\hline & Total & 64 & 420 & & \\
\hline \multirow{3}{*}{$\begin{array}{l}\text { Personal verbal } \\
\text { reminder }{ }^{b}\end{array}$} & Yes & $22(34)$ & $52(12)$ & 2.9 & $1.6,5.4$ \\
\hline & No & $42(66)$ & $369(88)$ & 1 & \\
\hline & Total & 64 & 421 & & \\
\hline \multirow[t]{3}{*}{ Sign on campus ${ }^{\mathrm{b}}$} & Yes & $16(25)$ & $64(15)$ & 2.8 & $1.4,5.6$ \\
\hline & No & $48(75)$ & $357(85)$ & 1 & \\
\hline & Total & 64 & 421 & & \\
\hline \multirow[t]{3}{*}{ Saw interviewer ${ }^{d}$} & Yes & $17(27)$ & $56(13)$ & 2.5 & $1.4,8.5$ \\
\hline & No & $46(73)$ & $364(87)$ & 1 & \\
\hline & Total & 63 & 420 & & \\
\hline \multirow[t]{3}{*}{ Class announcement ${ }^{e}$} & Yes & $25(39)$ & $67(16)$ & 2.4 & $1.3,4.8$ \\
\hline & No & $39(61)$ & $354(84)$ & 1 & \\
\hline & Total & 64 & 421 & & \\
\hline
\end{tabular}

${ }^{a}$ May not add to 100 due to rounding error

${ }^{\mathrm{b}}$ Adjusted for nationality

c Adjusted for nationality, having an academic deadline on the day of the blood drive, and number of hours of class between 9am and 12pm on the day of the blood drive

${ }^{\mathrm{d}}$ Adjusted for residence and number of hours of class between $12 \mathrm{pm}$ and $3 \mathrm{pm}$ on the day of the blood drive

${ }^{\mathrm{e}}$ Adjusted for school

heard an announcement in class regarding a blood drive were $3.4(95 \%$ CI: $0.9,12.7)$ times as likely to donate blood than those who had neither seen a sign nor heard an announcement (Table 3), but were just as likely (RR $=1.2 ; 95 \%$ CI: $0.3,4.5)$ to donate blood as those who had only heard a class announcement. Students who had both received an email and heard a class announcement were 5.9 (95\% CI: $2.2,16.0)$ times as likely to donate than those who had experienced neither, slightly less likely $(\mathrm{RR}=0.7 ; 95 \% \mathrm{CI}: 0.2,2.2)$ to donate than those who had received an email and heard no class announcement, but 
Table 3: Distribution of blood donors (cases) and non-donors (controls) by combined sources of blood drive information along with adjusted risk ratios (RRs) and 95\% confidence intervals (CIs) for associations between combined sources of information and blood donation, St George's University campus blood drive, Grenada, West Indies, February to April 2010

\begin{tabular}{|c|c|c|c|c|c|}
\hline Source of blood drive information & Categories & $\begin{array}{l}\text { Cases } \\
\text { n }(\%)^{\mathrm{a}}\end{array}$ & $\begin{array}{l}\text { Controls } \\
\text { n }(\%)^{\mathrm{a}}\end{array}$ & $\mathbf{R R}$ & $95 \% \mathrm{CI}$ \\
\hline \multirow[t]{5}{*}{ Sign and class announcement ${ }^{\mathrm{b}}$} & Both & $4(6)$ & $8(2)$ & 3.4 & $0.9,12.7$ \\
\hline & Sign only & $12(19)$ & $56(13)$ & 4.0 & $1.7,9.3$ \\
\hline & $\begin{array}{l}\text { Class announcement } \\
\text { only }\end{array}$ & $21(33)$ & $59(14)$ & 2.9 & $1.5,5.8$ \\
\hline & Neither & $27(42)$ & $298(71)$ & 1 & \\
\hline & Total & 64 & 421 & & \\
\hline \multirow[t]{5}{*}{ Sign and personal verbal reminder ${ }^{c}$} & Both & $7(11)$ & $10(2)$ & 6.9 & $2.3,20.5$ \\
\hline & Sign only & $9(14)$ & $54(13)$ & 2.4 & $1.0,5.6$ \\
\hline & $\begin{array}{l}\text { Personal verbal } \\
\text { reminder only }\end{array}$ & $15(23)$ & $42(10)$ & 2.6 & $1.3,5.3$ \\
\hline & Neither & $33(52)$ & $315(75)$ & 1 & \\
\hline & Total & 64 & 421 & & \\
\hline \multirow[t]{5}{*}{ Sign and Facebook post ${ }^{\mathrm{d}}$} & Both & $4(6)$ & $3(1)$ & 10.5 & $2.0,54.2$ \\
\hline & Sign only & $12(19)$ & $61(14)$ & 2.5 & $1.1,5.6$ \\
\hline & Facebook post only & $12(19)$ & $19(4)$ & 4.1 & $1.7,9.6$ \\
\hline & Neither & $36(56)$ & $338(80)$ & 1 & \\
\hline & Total & 64 & 421 & & \\
\hline \multirow[t]{5}{*}{ Class announcement and email ${ }^{\mathrm{e}}$} & Both & $9(14)$ & $13(3)$ & 5.9 & $2.2,16.0$ \\
\hline & $\begin{array}{l}\text { Class announcement } \\
\text { only }\end{array}$ & $16(25)$ & $54(13)$ & 2.9 & $1.3,6.1$ \\
\hline & Email only & $14(22)$ & $24(6)$ & 8.4 & $3.7,19.1$ \\
\hline & Neither & $25(39)$ & $330(78)$ & 1 & \\
\hline & Total & 64 & 421 & & \\
\hline \multirow[t]{5}{*}{ Personal verbal reminder and Facebook post ${ }^{\mathrm{f}}$} & Both & $5(8)$ & $5(1)$ & 8.5 & $2.1,35.0$ \\
\hline & $\begin{array}{l}\text { Personal verbal } \\
\text { reminder only }\end{array}$ & $17(27)$ & $47(11)$ & 3.3 & $1.6,6.7$ \\
\hline & Facebook only & $11(17)$ & $17(4)$ & 5.8 & $2.4,14.2$ \\
\hline & Neither & $31(48)$ & $352(84)$ & 1 & \\
\hline & Total & 64 & 421 & & \\
\hline \multirow[t]{5}{*}{ Personal verbal reminder and email ${ }^{\mathrm{g}}$} & Both & $8(12)$ & $9(2)$ & 10.2 & $3.4,30.5$ \\
\hline & $\begin{array}{l}\text { Personal verbal } \\
\text { reminder only }\end{array}$ & $14(22)$ & $43(10)$ & 3.1 & $1.4,6.6$ \\
\hline & Email only & $15(23)$ & $27(6)$ & 7.0 & $3.2,15.4$ \\
\hline & Neither & $27(42)$ & $342(81)$ & 1 & \\
\hline & Total & 64 & 421 & & \\
\hline
\end{tabular}

${ }^{a}$ May not add to 100 due to rounding error

${ }^{\mathrm{b}}$ Adjusted for residence, nationality, total hours of class on the day of the blood drive, and having an academic deadline the day after the blood drive

${ }^{\mathrm{c}}$ Adjusted for nationality

${ }^{d}$ Adjusted for nationality, residence, having an academic deadline within the week of the blood drive, residence, and number of hours of class between $12 \mathrm{pm}$ and $3 \mathrm{pm}$ on the day of the blood drive

${ }^{\mathrm{e}}$ Adjusted for school and total hours of class on the day of the blood drive

${ }^{\mathrm{f}}$ Adjusted for nationality, gender and having an academic deadline on the day after the blood drive

${ }^{g}$ Adjusted for school, number of hours of class between $9 \mathrm{am}$ and $12 \mathrm{pm}$ on the day of the blood drive, and number of hours of class between $12 \mathrm{pm}$ and $3 \mathrm{pm}$ on the day of the blood drive 
$2.9(95 \% \mathrm{CI}: 1.1,7.5)$ times as likely to donate than those who had heard an announcement but received no email.

\section{Assignments within a week of the blood drive}

In general, students who did not have an academic deadline in close proximity to the blood drive were more likely to donate blood than those who did, with the highest relative risks observed for not having an academic deadline at any time within the same week of the blood drive (RR $=1.9 ; 95 \%$ CI: 1.0, 3.7) (Table 4). Nevertheless, students who did not have an assignment the day before the blood drive were just as likely to donate as those who had an assignment $(\mathrm{RR}=1.1 ; 95 \% \mathrm{CI}: 0.6,1.9)$.

Table 4: Distribution of blood donors (cases) and non-donors (controls) by proximity of academic deadlines ${ }^{a}$ to the day of a campus blood drive along with adjusted risk ratios (RRs) and $95 \%$ confidence intervals (CIs) for associations between proximity of academic deadlines $^{\mathrm{a}}$ and blood donation, St George's University campus blood drive, Grenada, West Indies, February to April 2010

\begin{tabular}{|c|c|c|c|c|c|}
\hline $\begin{array}{l}\text { Proximity of aca- } \\
\text { demic deadlines to } \\
\text { day of blood drive }\end{array}$ & Categories & $\begin{array}{l}\text { Cases } \\
\text { n (\%) }\end{array}$ & $\begin{array}{l}\text { Controls } \\
\text { n (\%) }\end{array}$ & $\mathbf{R R}$ & $95 \% \mathrm{CI}$ \\
\hline \multirow[t]{3}{*}{ None the same week ${ }^{b}$} & Yes & $26(38)$ & $95(22)$ & 1.9 & $1.0,3.7$ \\
\hline & No & $43(62)$ & $335(78)$ & 1 & \\
\hline & Total & 69 & 430 & & \\
\hline \multirow[t]{3}{*}{ None the day before ${ }^{c}$} & Yes & $40(58)$ & 247 (57) & 1.1 & $0.6,1.9$ \\
\hline & No & $29(42)$ & $183(43)$ & 1 & \\
\hline & Total & 69 & 430 & & \\
\hline \multirow{3}{*}{$\begin{array}{l}\text { None on the same } \\
\text { day }^{\mathrm{d}}\end{array}$} & Yes & $55(80)$ & $284(66)$ & 1.7 & $0.9,3.3$ \\
\hline & No & $14(20)$ & $144(34)$ & 1 & \\
\hline & Total & 69 & 428 & & \\
\hline \multirow[t]{3}{*}{ None on the day after } & Yes & $49(71)$ & $247(58)$ & 1.5 & $0.9,2.7$ \\
\hline & No & $20(29)$ & $180(42)$ & 1 & \\
\hline & Total & 69 & 427 & & \\
\hline \multirow[t]{3}{*}{ None the week after ${ }^{f}$} & Yes & $20(29)$ & $81(19)$ & 1.8 & $1.0,3.1$ \\
\hline & No & $49(71)$ & $350(81)$ & 1 & \\
\hline & Total & 69 & 431 & & \\
\hline
\end{tabular}

${ }^{a}$ Include assignment deadlines and assessments

${ }^{\mathrm{b}}$ Adjusted for nationality, not having an academic deadline the day before the blood drive, and not having an academic deadline the day after the blood drive ${ }^{\mathrm{c}}$ Adjusted for nationality and not having an academic deadline the week after the blood drive

${ }^{\mathrm{d}}$ Adjusted for not having an academic deadline the day after the blood drive

${ }^{\mathrm{e}}$ Adjusted for not having an academic deadline the day of the blood drive

${ }^{\mathrm{f}}$ No variable changed crude RR estimate by more than $10 \%$

\section{Hours of class on the day of the blood drive}

Students who did not have class in the morning (9am$12 \mathrm{pm}$ ) were more likely to donate blood than those who did (Table 5). A similar pattern was observed for afternoon (12-3pm) classes, with students who did not have afternoon classes more likely to donate than those who had afternoon classes. Finally, having no classes (9am-3pm) on the day of the blood drive was more consistent with a lower likelihood than a higher likelihood of donating blood (Table 5).

Table 5: Distribution of blood donors (cases) and non-donors (controls) by class schedules between $9 \mathrm{am}$ and $3 \mathrm{pm}$ on the day of a campus blood drive, along with adjusted risk ratios (RRs) and 95\% confidence intervals (CIs) for associations between class schedule and blood donation, St George's University, Grenada, West Indies, February to April 2010

\begin{tabular}{llllll}
\hline $\begin{array}{l}\text { Class time on day of } \\
\text { blood drive }\end{array}$ & Categories & $\begin{array}{l}\text { Cases } \\
\mathbf{n}(\%)\end{array}$ & $\begin{array}{l}\text { Controls } \\
\mathbf{n}(\%)\end{array}$ & RR & 95\% CI \\
\hline $9 \mathrm{am}-12 \mathrm{pm}^{\mathrm{a}}$ & No & $13(19)$ & $78(18)$ & 1.5 & $0.7,2.9$ \\
& Yes & $56(81)$ & $355(82)$ & 1 & \\
& Total & 69 & 433 & & \\
& & & & & \\
$12-3 \mathrm{pm}^{\mathrm{b}}$ & No & $35(51)$ & $150(35)$ & 1.9 & $1.2,3.2$ \\
& Yes & $34(49)$ & $282(65)$ & 1 & \\
& Total & 69 & 432 & & \\
& & & & & \\
$9 \mathrm{am}-3 \mathrm{pm}^{\mathrm{c}}$ & No & $4(6)$ & $28(6)$ & 0.5 & $0.1,2.3$ \\
& Yes & $65(94)$ & $406(94)$ & 1 & \\
& Total & 69 & 434 & & \\
\hline
\end{tabular}

${ }^{a}$ Adjusted for school

${ }^{\mathrm{b}}$ No variable changed crude RR estimate by more than $10 \%$

${ }^{\mathrm{c}}$ Adjusted for school, number of hours of class between $9 \mathrm{am}$ and $12 \mathrm{pm}$ on the day of the blood drive, and number of hours of class between $12 \mathrm{pm}$ and $3 \mathrm{pm}$ on the day of the blood drive

\section{DISCUSSION}

This study adds to existing research on tertiary student blood donation by linking factors occurring in close temporal proximity to a university campus blood drive to actual donation. We believe this is the first case-control study to address this issue and one of few studies on student blood donation conducted in the context of a blood drive $(6,15,19,30-32)$.

All sources of advertising the blood drives were associated with a substantial (two-fold or more) increase in the likelihood of students donating. This suggests that all of these sources of blood drive information are likely to increase blood donation if instituted in close proximity to a blood drive. The strong associations observed for Facebook and email reminders are consistent with electronic media being common and effective tools for communication among tertiary students $(33,34)$.

The association of 'saw donor' and 'saw interviewer' with blood donation suggests that on the day of the blood drive, making donors and other persons associated with a blood drive easily recognizable might be an effective 
means of blood drive promotion. Previous work has suggested that having blood drive affiliates wear shirts advertising the blood drive $(30,31)$ and being asked to donate blood by a donor (32) might increase the number of donors on a blood drive day. It is likely that the visual effect of seeing these persons serves to trigger or reinforce the decision to donate. Associations with blood donation observed for combined sources of information suggest that specific sources of information used jointly in a targeted manner could have an advantageous effect on blood donation compared to when used singly. This seems particularly true for combinations of personal verbal reminders with emails or Facebook posts. In addition to electronic communications being frequently used by tertiary students, a possible explanation for this may be that both personal verbal reminders and electronic communications were likely to be direct and also come from personal acquaintances. Previous reports have suggested that direct requests and solicitations by personal acquaintances were likely to have a more positive effect on blood donation than the use of signs $(6,18,32)$. The fact that the combination of class announcement and sign (a combination of two impersonal means of communication) showed no greater association with blood donation than class announcement or sign individually also supports a view that in a targeted campaign, it would be best to include at least one personal means of advertising for maximum effect.

The increased likelihood of blood donation by students who did not have assignments due within either the same week or the week after the blood drive, compared to those who did, was consistent with an expectation that students were more likely to donate blood when they did not have academic deadlines in close proximity to the blood drive. In addition to time-related concerns, a potential explanation for this is a concern by students that blood donation might negatively affect their academic performance because of consequent feelings of dizziness and/or weakness. Both of these explanations have previously been cited as deterrents to blood donation $(4,9,16)$.

The fact that students who did not have classes in the morning and students who did not have classes in the afternoon on the day of the blood drive were more likely to donate blood than those who had classes in the afternoon and morning, respectively, suggests that ensuring that blood donation is possible at a time that does not conflict with class schedules is beneficial to increasing blood donation. It is likely that rather than just hours of class on the day, it is also the presence of a sufficient block of time for blood donation which determines whether donation occurs. If so, it is unlikely that blocks of time in excess of the required amount will result in an increase in the rate of blood donation. This view is supported by the observation that results for students with no classes at all on the day of the blood drive were more consistent with lower than higher likelihoods of donating (Table 5).

Comprehensively, these results suggest that it would be advantageous to plan blood drives during periods when students were less likely to have major academic assignments and to ensure that the hours of the blood drive were extended long enough to guarantee even students with very packed timetables an ample block of time within which to donate. The most feasible way to do this would be to organize student group-specific blood drives targeting students at similar stages of their academic career.

Low numbers of blood donors resulted in imprecise RR estimates for some exposures of interest and prevented examination of the potential modifying effects of nationality and school of enrolment on the exposures of interest. Notwithstanding this, we believe this report makes a valuable contribution to the literature on student blood donation, as the quantification of these associations provides empirical and concrete evidence on which marketing campaign strategies can be based.

\section{CONCLUSION}

Firstly, this study revealed that personal and/or electronic modes of advertising university blood drives were more strongly associated with university student blood donation than impersonal and non-electronic modes of advertising. Secondly, university students were more likely to donate blood if they did not have class assignments within a week of the blood drive. Thirdly, if in addition to having few classes on the day of the drive, students were provided with a sufficient block of time in which to donate blood, they would be more likely to do so. Given that students are likely to have closer relationships with classmates than with non-classmates, they should be asked to advertise blood drives to their classmates via personal reminders, emails, Facebook messages and other forms of electronic media. Personal reminders should be followed up with, or preceded by, class announcements along with signs placed at strategic places on campus. It is likely advantageous to plan blood drives around the timetables of homogenous groups of students at similar stages of their academic career as they should have similar timetables. Finally, rendering 
donors and blood drive affiliates conspicuous to the campus population is also likely to increase the number of blood donors on the day.

While this study was conducted in the context of blood drives organized by SGU's American Medical Student Association and the GBB, student communication strategies as well as student class schedules and academic assignment schedules are features of all university environments. Thus, these results should have relevance to organizations which conduct blood drives on other university campuses within as well as outside of the West Indies.

\section{ACKNOWLEDGEMENTS}

We would like to acknowledge the help provided by our 30 student interviewers who performed data collection.

\section{AUTHORS' NOTE}

The authors have no conflicts of interest to declare.

\section{REFERENCES}

1. Falconí RS, Medina JG, Soto CL, Franco JLR. Características de la donación de sangre en estudiantes de la Facultad de Medicina Humana de la Universidad de San Martín de Porres [Blood donation characteristics in students of the School of Human Medicine at the University of San Martin de Porres]. Revista Horizonte Medico 2006; 6: 89-97. Available from: www.horizontemedicina.usmp.edu.pe/index.php/ horizontemed/article/view/234.

2. Go SL, Lam CT, Lin YT, Wong DJ, Lazo-Langner A, Chin-Yee I. The attitude of Canadian university students toward a behavior-based blood donor health assessment questionnaire. Transfus 2011; 51: 742-52.

3. Nonis SA, Ford CW, Logan L, Hudson G. College student's blood donation behavior: relationships to demographics, perceived risk, and incentives. Health Mark Q 1996; 13: 33-46.

4. Shaz BH, Demmons DG, Crittenden CP, Carnevale CV, Lee M, Burnett $\mathrm{M}$ et al. Motivators and barriers to blood donation in African American college students. Transfus Apher Sci 2009; 41: 191-7.

5. Hupfer ME, Taylor DW, Letwin JA. Understanding Canadian student motivations and beliefs about giving blood. Transfus 2005; 45: 149-61.

6. McCombie RP. Blood donation patterns of undergraduate students: family and friendship correlates. J Community Psychol 1991; 19: 161-5.

7. Oswalt RM, Napoliello M. Motivations of blood donors and nondonors. J Appl Psychol 1974; 59: 122-4.

8. Jalalian M, Latiff L, Hassan ST, Hanachi P, Othman M. Development of a questionnaire for assessing factors predicting blood donation among university students: a pilot study. Southeast Asian J Trop Med Public Health 2010; 41: 660-6.

9. Salaudeen AG, Odeh E. Knowledge and behavior towards voluntary blood donation among students of a tertiary institution in Nigeria. Nigerian J Clin Pract 2011; 14: 303-7.

10. Wiwanitkit $\mathrm{V}$. Knowledge about blood donation among a sample of Thai university students. Vox Sang 2002; 83: 97-9.

11. Safizadeh H, Pourdamghan N, Mohamadi B. University students awareness and attitude towards blood donation in Kerman City. Iran J Blood and Cancer 2009; 1: 107-10.

12. Karakkamandapam S, Remya A, Binu VS, Raghavan V. Knowledge, attitude and practice on blood donation among Health Science Students in a university campus, South India. Online J Health Allied Sciences 2011; 10: 1-3.
13. Batiha AM, AlBashtawy M. Knowledge of Philadelphia University students regarding blood donation. Transfus Med 2013; 23: 195-8.

14. Vásquez M, Ibarra P, Maldonado M. Conocimientos y actitudes hacia la donación de sangre, en una población universitaria de Chile [Blood donation: knowledge and attitudes of a university population in Chile]. Rev Panam Salud Publica 2007; 22: 323-8.

15. Gader AGMA, Osman AMA, Al Gahtani FH, Farghali MN, Ramadan AH, Al-Momen AKM. Attitude to blood donation in Saudi Arabia. Asian J Transfus Sci 2011; 5: 121-6.

16. Cardona Arias J. Conocimientos, actitudes y prácticas sobre la donación de sangre en estudiantes universitarios [Knowledge, attitudes and practices regarding blood donation in undergraduate students]. Medicina UPB 2012; 30: 121-31.

17. Siddiqui UF, Yasmeen A, Hina N, Alam SN. Who donates more; medical or non-medical students. J Dow Univ Health Sciences 2013; 6: 17-21.

18. Hurst K, Leigh L, Bist M, Alexe R. Marketing blood drives to students: a case study. Int J Health Care Quality Assurance 2007; 20: 84-95.

19. Ngoma AM, Goto A, Yamazaki S, Machida M, Kanno T, Nollet KE et al. Barriers and motivators to blood donation among university students in Japan: development of a measurement tool. Vox Sang 2013; 105: 219-24.

20. Wagner TR, Manolis C. The fear associated with blood and organ donation: an explication of fright and anxiety. Prog Transplant 2012; 22: $200-6$.

21. Saleem S, Wasim A, Sabih S, Khan AF, Rizvi MH, Jillani UA et al. Assessing acceptability of short message service based interventions towards becoming future voluntary blood donors. J Blood Transfus 2014; 2014: 1-6.

22. Di Pascuale S, Galíndez M, Guevara H, Hernández M. Disposición a la donación voluntaria de sangre en estudiantes de Ciencias de la Salud. Salus: Rev de la Facultad de Ciencias de la Salud, Universidad de Carabobo 2008; 12: 6-9.

23. Sharma R, Kannan AT, Lukhmana S, Gupta N. The chasm between blood donation intention and action: a study among college students in Delhi, India. IJDHD 2012; 11: 255-9.

24. Dean BW, Hewitt SN, Begos MC, Gomez A, Messam LLMV. An analysis of blood donation barriers experienced by North American and Caribbean university students in Grenada, West Indies. Transfus Apher Sci 2018; 57: 40-5.

25. Gomez A, Messam L, Toner L. Collaboration and research as key elements for strengthening blood donation in developing nations: the case of Grenada, West Indies. West Indian Med J 2013; 62: 48-56.

26. Cruz JR, Perez-Rosales MD. Availability, safety, and quality of blood for transfusion in the Americas. Rev Panam Salud Publica 2003; 13: $103-10$.

27. Greenland S, Pearl J, Robins JM. Causal diagrams for epidemiologic research. Epidemiology 1999; 10: 37-48.

28. Greenland S. Modeling and variable selection in epidemiologic analysis. Am J Public Health 1989; 79: 340-9.

29. Knol MJ, Vandenbroucke JP, Scott P, Egger M. What do case-control studies estimate? Survey of methods and assumptions in published casecontrol research. Am J Epidemiol 2008; 168: 1073-81.

30. Charles-Sire V, Gueguen N, Pascual A, Meineri S. Words as environmental cues: the effect of the word 'loving' on compliance to a blood donation request. J Psychol 2012; 146: 455-70.

31. Gueguen N. 'Even a donation one time in your live will help...': the effect of the legitimizing paltry contribution technique on blood donation. Transfus Apher Sci 2013; 49: 489-93.

32. Jason LA, Rose T, Ferrari JR, Barone R. Personal versus impersonal methods for recruiting blood donations. J Soc Psychol 1984; 123: 139-40.

33. Pempek TA, Yermolayeva YA, Calvert SL. College students' social networking experiences on Facebook. J Appl Dev Psychol 2009; 30: 227-38.

34. Jones S. The internet goes to college: how students are living in the future with today's technology. Pew Internet and American Life Project $2002 ; 1-23$. 